\title{
Fit-for-Purpose ICP-MS Procedure Supporting Brazilian Regulations on Inorganic Constituents in Fresh and Saline Waters
}

\author{
Fernanda C. Pinheiro, ${ }^{a}$ Rodolfo Lorençatto, ${ }^{b}$ Ariane I. Barros, ${ }^{a}$ Clarice D. B. Amaral \\ and Joaquim A. Nóbrega ${ }^{*, a}$ \\ ${ }^{a}$ Grupo de Análise Instrumental Aplicada, Departamento de Química, \\ Universidade Federal de São Carlos, P.O. Box 676, 13560-270 São Carlos-SP, Brazil \\ ${ }^{b}$ Agilent Technologies, 06460-040 São Paulo-SP, Brazil \\ ${ }^{c}$ Departamento de Química, Universidade Federal do Paraná, 81531-980 Curitiba-PR, Brazil
}

\begin{abstract}
This work aimed the development of an analytical procedure using inductively coupled plasma mass spectrometry (ICP-MS) in four modes of operation for simple and fast determination of $\mathrm{Al}$, $\mathrm{Ag}$, As, B, Ba, Be, Ca, Cd, Co, Cr, Cu, Fe, Li, Mg, Mn, Na, Ni, Pb, Sb, Se, Tl, Hg, V, U, and Zn in fresh and sea water samples attending simultaneously four Brazilian regulations, Ordinance No. 2914, ANVISA No. 274 and CONAMA Nos. 357 and 396. High matrix introduction system enables the introduction of sea water $\left(3.5 \% \mathrm{~m} \mathrm{v}^{-1}\right.$ of $\left.\mathrm{NaCl}\right)$ only 2 -fold diluted. Collision cell mode was efficient to overcome polyatomic interferences. The procedure presented limits of detection (LODs) lower than maximum concentrations allowed by regulations. The CRM NIST $1643 \mathrm{e}$ and addition-recovery experiments were used to check accuracy and recoveries varied from 84 to $115 \%$. ICP-MS combined with collision cell mode and aerosol dilution led to accurate and simultaneous determinations of 25 elements at different concentration levels in samples containing high contents of total dissolved solids.
\end{abstract}

Keywords: water, Brazilian regulations, HMI, collision cell, ICP-MS

\section{Introduction}

Essential micronutrients present in water, such as $\mathrm{Cu}$ and $\mathrm{Se}$, have important roles in the body functioning. However, at excessive concentrations, they can negatively affect growth, reproduction and several biological functions. On the other hand, the presence of toxic elements, such as $\mathrm{Cd}$ and $\mathrm{Pb}$, is extremely damaging, even at trace concentrations

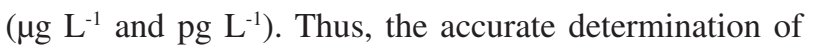
toxic and essential elements in water is crucial for human health safety.

In this context, four Brazilian regulations, Ordinance No. 2914/2011 ${ }^{2}$ of the Ministry of Health, Resolution RDC No. 274/2005 3 and CONAMA Resolutions Nos. 357/2005 and 396/20085 establish maximum values for physicochemical and chemical parameters in water samples. Ordinance No. $2914^{2}$ establishes maximum values and procedures for controlling and monitoring of water quality. Resolution RDC No. $274^{3}$ establishes secure identity

*e-mail: djan@ufscar.br and quality characteristics for natural mineral water, natural water and ice for human consumption. CONAMA Resolution No. $357^{4}$ establishes maximum values for natural waters (surface, brackish and saline water) and CONAMA Resolution No. $396^{5}$ establishes classification and maximum values for groundwater.

Thus, the development of sensitive and accurate analytical procedures for elemental analysis of water is required. Among the analytical instrumental methods, inductively coupled plasma mass spectrometry (ICP-MS) provides fast multi-elemental analysis, low detection limits (LOD), high sensitivity, precision and robustness. However, the determination of some isotopes is limited by the occurrence of spectral interferences. ${ }^{6}$ In addition, sample dilution is often required to keep the total dissolved solids (TDS) below $0.1 \% \mathrm{~m} \mathrm{v}^{-1}$ and acidity below $2 \% \mathrm{v} \mathrm{v}^{-1}$.

In order to eliminate spectral interferences, collision cell technology (CCT) features a cell introduced before the mass analyzer. Collision cell provides effective correction of polyatomic interferences, eliminating the need for reactive cell gases in routine analysis. ${ }^{7-9}$ Additionally, high matrix 
introduction (HMI) technology uses auto-optimization of aerosol dilution to further improve matrix tolerance, reducing both aerosol density and water vapor loading in the plasma. ${ }^{8,10-16}$

Wilbur and Jones ${ }^{8}$ demonstrated the benefits of HMI system for determination of 26 elements in complex matrix certified reference materials (CRM), such as river sediment and soil samples. Aqueous samples were investigated using fast protein liquid chromatography (FPLC) coupled to ICP-MS with a high matrix introduction system. The HMI reduced the sample aerosol transport and enabled direct analysis of separated $\mathrm{Cr}$ species in the presence of up to $4 \% \mathrm{~m} \mathrm{v}^{-1} \mathrm{NaCl}^{13}$

In this context, this study presents the development of an analytical procedure using a quadrupole ICP-MS operated in four acquisition modes: (i) No gas: standard mode; (ii) No gas (HMI): standard mode with HMI system; (iii) He: collision cell mode; (iv) He (HMI): collision cell mode with HMI system; for determination of $\mathrm{Al}, \mathrm{Ag}, \mathrm{B}, \mathrm{Ba}, \mathrm{Be}, \mathrm{Ca}, \mathrm{Cd}, \mathrm{Co}, \mathrm{Cr}, \mathrm{Cu}, \mathrm{Fe}, \mathrm{Li}, \mathrm{Mg}, \mathrm{Mn}, \mathrm{Na}$, $\mathrm{Ni}, \mathrm{Pb}, \mathrm{Sb}, \mathrm{Se}, \mathrm{Tl}, \mathrm{Hg}, \mathrm{V}, \mathrm{U}$ and $\mathrm{Zn}$ in natural fresh water (Tables I, II and III of CONAMA 357); ${ }^{4}$ mineral and tap water samples in order to meet simultaneously Ordinance 2914/11, ${ }^{2}$ CONAMA $357 / 05^{4}$ and ANVISA 274/05. Aluminum, Ag, B, As, Ba, Be, Cd, Cr, Cu, Fe, Mn, Ni, Pb, $\mathrm{Se}, \mathrm{Hg}, \mathrm{U}$ and $\mathrm{Zn}$ were determined in sea water (Tables IV and V of CONAMA 357$)^{4}$ providing higher sample throughput and lower argon consumption by allowing the determination of all elements in a single run.

\section{Experimental}

\section{Instrumentation}

Analysis was performed using an Agilent 7800 Quadrupole ICP-MS (Agilent Technologies, Tokyo, JHS, Japan) operated in four acquisition modes: (i) No gas; (ii) No gas (HMI); (iii) He and (iv) He (HMI). No gas mode means not using the collision cell and He mode means that collision cell is pressurized with pure He $(99.999 \%$, White Martins-Praxair, Sertãozinho, SP, Brazil). Plasma operating conditions are described in Table 1. HMI mode implies that aerosol was diluted with argon at the optimized HMI gas flow rate of $0.62 \mathrm{~L} \mathrm{~min}^{-1}$ and carrier gas flow rate of $0.40 \mathrm{~L} \mathrm{~min}^{-1}$, thus $1.02 \mathrm{~L} \mathrm{~min}^{-1}$ of total flow rate. Argon (99.9996\%, White Martins-Praxair, Sertãozinho, SP, Brazil) was used for all measurements. Mira Mist nebulizer (Burgener Research, Mississauga, ON, Canada) was used due to the eventual presence of solid particles in natural water samples. The reading time, considering these four modes of operation, plus sample collection and rinse times,
Table 1. Operating parameters used in Agilent 7800 Quadrupole ICP-MS

\begin{tabular}{|c|c|}
\hline Instrument parameter & Operating condition \\
\hline RF applied power / $\mathrm{kW}$ & 1.55 \\
\hline Plasma gas flow rate / $\left(\mathrm{L} \mathrm{min}{ }^{-1}\right)$ & 15 \\
\hline Auxiliary gas flow rate / $\left(\mathrm{L} \mathrm{min}^{-1}\right)$ & 1.0 \\
\hline Carrier gas flow rate / $\left(\mathrm{L} \mathrm{min}^{-1}\right)$ & 1.02 \\
\hline 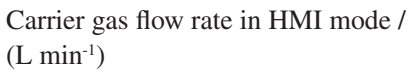 & 0.40 \\
\hline HMI gas flow rate / $\left(\mathrm{L} \mathrm{min}^{-1}\right)$ & 0.62 \\
\hline Sampling depth / mm & 8 \\
\hline $\begin{array}{l}\text { He flow rate in collision cell / } \\
\left(\mathrm{mL} \mathrm{min}^{-1}\right)\end{array}$ & 4.5 \\
\hline Integration time / s & 3 \\
\hline Nebulizer & concentric nebulizer - glass \\
\hline Spray chamber & Scott type - double pass \\
\hline Number of replicates & 3 \\
\hline Isotopes monitored & $\begin{array}{c}{ }^{7} \mathrm{Li}^{+},{ }^{9} \mathrm{Be}^{+},{ }^{11} \mathrm{~B}^{+},{ }^{23} \mathrm{Na}^{+},{ }^{24} \mathrm{Mg}^{+},{ }^{27} \mathrm{Al}^{+}, \\
{ }^{44} \mathrm{Ca}^{+},{ }^{11} \mathrm{~V}^{+},{ }^{52} \mathrm{Cr}^{+},{ }^{55} \mathrm{Mn}^{+},{ }^{6} \mathrm{Fe}^{+}, \\
{ }^{58} \mathrm{Ni}^{+},{ }^{59} \mathrm{Co}^{+},{ }^{64} \mathrm{Zn}^{+},{ }^{65} \mathrm{Cu}^{+},{ }^{74} \mathrm{Ge}^{+}, \\
{ }^{75} \mathrm{As}^{+},{ }^{78} \mathrm{Se}^{+},{ }^{107} \mathrm{Ag}^{+},{ }^{114} \mathrm{Cd}^{+},{ }^{115} \mathrm{In}^{+}, \\
{ }^{123} \mathrm{Sb}^{+},{ }^{137} \mathrm{Ba}^{+},{ }^{193} \mathrm{Ir}^{+},{ }^{195} \mathrm{Pt}^{+},{ }^{202} \mathrm{Hg}^{+}, \\
{ }^{205} \mathrm{Tl}^{+},{ }^{208} \mathrm{~Pb}^{+} \text {and }{ }^{238} \mathrm{U}^{+}\end{array}$ \\
\hline
\end{tabular}

ICP-MS: inductively coupled plasma mass spectrometry; RF: radio frequency; HMI: high matrix introduction.

totalized approximately 4 min per sample at $1.0 \mathrm{~mL} \mathrm{~min}^{-1}$ of sample uptake rate.

\section{Reagents, standard solutions and samples}

Experiments were performed using $\mathrm{HNO}_{3}$ (Synth, Diadema, SP, Brazil) purified in a sub-boiling distillation system Distillacid ${ }^{\mathrm{TM}}$ BSB-939-IR (Berghof, Eningen, Germany) and ultrapure water, resistivity higher than 18.2 M $\Omega$ cm (Milli-Q ${ }^{\circledast}$, Millipore, Bedford, MA, USA). Standard solutions used for ICP-MS calibration and for addition and recovery experiments were prepared by dilution of $1000 \mathrm{mg} \mathrm{L}^{-1}$ of Al, Ag, As, B, Ba, Be, Ca, Cd, $\mathrm{Co}, \mathrm{Cr}, \mathrm{Cu}, \mathrm{Fe}, \mathrm{Li}, \mathrm{Mg}, \mathrm{Mn}, \mathrm{Na}, \mathrm{Ni}, \mathrm{Pb}, \mathrm{Sb}, \mathrm{Se}, \mathrm{Tl}, \mathrm{Hg}, \mathrm{V}$, $\mathrm{U}$ and $\mathrm{Zn}$ (Qhemis, São Paulo, Brazil) in $0.14 \mathrm{~mol} \mathrm{~L}^{-1} \mathrm{HNO}_{3}$ medium, as well as the internal standards (ISs) evaluated: $\mathrm{Ge}, \mathrm{Li}, \mathrm{In}, \mathrm{Ir}$ and Pt.

For fresh water analysis, the concentrations of the solutions used for obtaining analytical calibration curves were $0,0.05,0.1,0.5,1.0,2.0,5.0,10,20$ and $50 \mu \mathrm{g} \mathrm{L}^{-1}$ for $\mathrm{Al}, \mathrm{Ag}, \mathrm{As}, \mathrm{B}, \mathrm{Be}, \mathrm{Cd}, \mathrm{Co}, \mathrm{Cr}, \mathrm{Cu}, \mathrm{Fe}, \mathrm{Li}, \mathrm{Mn}, \mathrm{Ni}, \mathrm{Pb}$, $\mathrm{Sb}, \mathrm{Se}, \mathrm{Tl}, \mathrm{V}, \mathrm{U}$ and $\mathrm{Zn}$. Barium concentrations were 0 , 1.0, 2.0, 5.0, 10, 50, 100, 200, 500 and $700 \mu \mathrm{g} \mathrm{L}^{-1}$. For $\mathrm{Hg}$, the concentrations were $0,0.01,0.05,0.1,0.2,0.5$, $1.0,1.5,3.0$ and $5.0 \mu \mathrm{g} \mathrm{L}^{-1}$. For elements present at high concentrations, such as $\mathrm{Na}$, calibration points were 0,10 , 50, 100, 150 and $200 \mathrm{mg} \mathrm{L}^{-1}$ and for $\mathrm{Ca}$ and $\mathrm{Mg}$ were 0 , $1.0,2.5,5.0,10$ and $20 \mathrm{mg} \mathrm{L}^{-1}$. 
For analysis of sea water, the concentrations of the solutions used for analytical calibration curves were 0 , 1.0, 2.0, 5.0, 10, 20, 50 and $100 \mu \mathrm{g} \mathrm{L}-1$ for $\mathrm{Al}, \mathrm{Ag}, \mathrm{As}, \mathrm{Ba}$, $\mathrm{Be}, \mathrm{Cd}, \mathrm{Cr}, \mathrm{Cu}, \mathrm{Fe}, \mathrm{Mn}, \mathrm{Ni}, \mathrm{Pb}, \mathrm{Se}, \mathrm{U}$ and $\mathrm{Zn}$ and for $\mathrm{Hg}$ were $0,0.05,0.1,0.2,0.5,1.0$ and $1.5 \mu \mathrm{L} \mathrm{L}^{-1}$, prepared by matrix-matching with $3.5 \% \mathrm{~m} \mathrm{v}^{-1}, 1.75 \% \mathrm{~m} \mathrm{v}^{-1} \mathrm{NaCl}$ (Merck, Rio de Janeiro, RJ, Brazil) and only in $0.14 \mathrm{~mol} \mathrm{~L}^{-1}$ $\mathrm{HNO}_{3}$ medium (without matrix-matching).

The certified reference material of trace elements in water, NIST SRM 1643e (National Institute of Standard and Technology, Gaithersburg, MD, USA), was used for optimization of experimental procedures and evaluation of accuracy. Addition and recovery experiments were performed for $\mathrm{Hg}$ and $\mathrm{U}$, both not present in the SRM 1643e. Analogously, for sea water analysis, addition and recovery experiments were performed at two addition levels 0.2 and $0.5 \mu \mathrm{g} \mathrm{L}-1$ for $\mathrm{Hg}$ and 10 and $25 \mu \mathrm{g} \mathrm{L}^{-1}$ for the other elements investigated. Internal standards were added at $10 \mu \mathrm{g} \mathrm{L}^{-1}$ to the analytical calibration solutions, analytical blanks and samples. The cleaning of the sample introduction system with $0.12 \mathrm{~mol} \mathrm{~L}^{-1} \mathrm{HCl}$ after measurement of each solution is mandatory for avoiding memory effects caused by mercury. ${ }^{17}$ Afterwards, a fast cleaning step with $0.14 \mathrm{~mol} \mathrm{~L}^{-1} \mathrm{HNO}_{3}$ solution was made for avoiding any undesirable effect caused by chloride.

Six mineral bottled waters purchased in local supermarkets, one sample of artesian well water (groundwater), one sample of drinking water from the Federal University of São Carlos, were directly analyzed without any pretreatment. One sea water sample from Caraguatatuba Beach (São Paulo State, Brazil) was analyzed after a 2 -fold dilution and filtration on $0.45 \mu \mathrm{m}$ filter paper.

\section{Optimization of the procedure}

The effect of HMI flow rate on sodium chloride solutions containing $0,0.1,0.5,1.7$ and $3.5 \% \mathrm{~m} \mathrm{v}^{-1}$ by dissolution of the pure salt in water and doped at $1 \mu \mathrm{g} \mathrm{L}^{-1}$ of all analytes were investigated by varying the dilution gas flow rate for HMI from 0.30 to $0.80 \mathrm{~L} \mathrm{~min}^{-1}$, also with the variation of the nebulization gas flow rate from 0.72 to $0.22 \mathrm{~L} \mathrm{~min}^{-1}$, with increments of $0.10 \mathrm{~L} \mathrm{~min}^{-1}$. In all experiments, the flow rate summation of both was kept at $1.02 \mathrm{~L} \mathrm{~min}^{-1}$. Isotopes were evaluated, as well as the $\mathrm{CeO}^{+} / \mathrm{Ce}^{+}$ratio.

For analysis of sea water, in order to optimize the acquisition mode (No gas (HMI) or He (HMI)) and aerosol dilution conditions, three analytical curves were prepared by matrix-matched with 3.5 and $1.75 \% \mathrm{~m} \mathrm{v}^{-1} \mathrm{NaCl}$, and $\mathrm{HNO}_{3} 1 \% \mathrm{v} \mathrm{v}^{-1}$ for sea water samples analysis without dilution, 2-fold dilution and 5-fold dilution, respectively.
The best working conditions were established based on addition and recovery experiments for each condition. For analysis of fresh water, the acquisition mode (No gas, No gas (HMI), He and He (HMI)) were established according to recoveries of the certified reference material of trace elements in water, NIST SRM 1643e. After optimization, the monitored isotopes and the acquisition mode were selected for each analyte.

\section{Results and Discussion}

\section{Effect of the HMI system for analysis of saline solutions}

Sea water is a high TDS matrix for plasma. Additionally, elemental detection in an $\mathrm{NaCl}$ matrix by ICP-MS is also affected by polyatomic interferences formed by chlorine ions, such as ${ }^{35} \mathrm{Cl}^{16} \mathrm{O}^{+}$affecting ${ }^{51} \mathrm{~V}^{+} ;{ }^{35} \mathrm{Cl}^{16} \mathrm{OH}^{+}$affecting ${ }^{52} \mathrm{Cr}^{+} ;{ }^{37} \mathrm{Cl}^{17} \mathrm{OH}^{+}$affecting ${ }^{55} \mathrm{Mn}^{+} ;{ }^{37} \mathrm{Cl}^{18} \mathrm{OH}^{+}$affecting ${ }^{56} \mathrm{Fe}^{+} ;{ }^{23} \mathrm{Na}^{35} \mathrm{Cl}^{+}$affecting ${ }^{58} \mathrm{Ni}^{+} ;{ }^{24} \mathrm{Mg}^{35} \mathrm{Cl}^{+}$affecting ${ }^{59} \mathrm{Co}^{+}$ and ${ }^{40} \mathrm{Ar}^{35} \mathrm{Cl}^{+}$affecting ${ }^{75} \mathrm{As}^{+}$in quadrupole based mass spectrometers. ${ }^{6,7}$

The effect of HMI use on chlorine interferences and oxide formation was evaluated by signal intensities monitoring for ${ }^{75} \mathrm{As}^{+} 1.0 \mu \mathrm{g} \mathrm{L}{ }^{-1}$ (Figure 1) and for $\mathrm{CeO}^{+} / \mathrm{Ce}^{+}$ ratio (Figure 2). These investigations were performed at 0 , $0.1,0.5,1.7$ and $3 \% \mathrm{~m} \mathrm{v}^{-1} \mathrm{NaCl}$ and different $\mathrm{HMI}$ gas flow rates $\left(0.30,0.40,0.50,0.60,0.70\right.$ and $\left.0.82 \mathrm{~L} \mathrm{~min}^{-1}\right)$ in $\mathrm{He}$ (HMI) and No gas (HMI) acquisition modes.

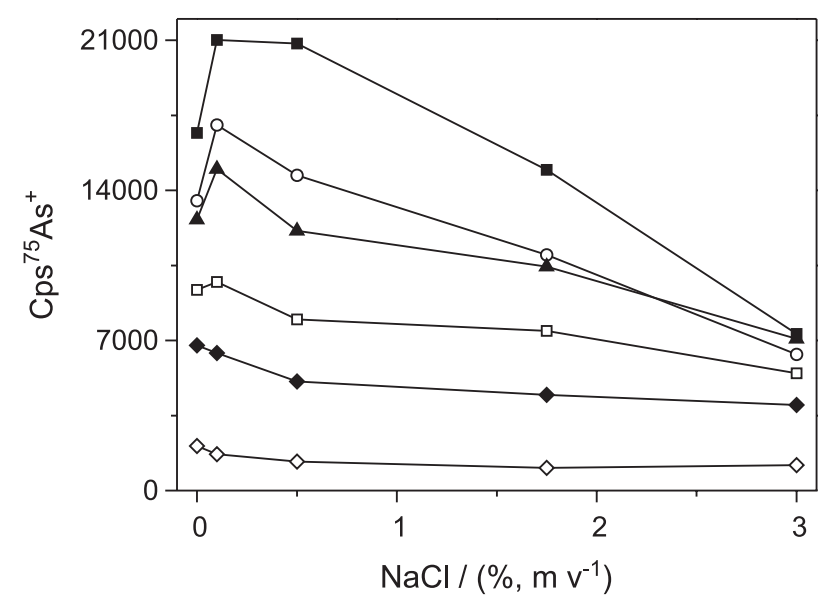

Figure 1. Effect of HMI (high matrix introduction) gas flow rate $\left(\mathrm{L} \mathrm{min}^{-1}\right)$ on ${ }^{75} \mathrm{As}^{+}$net signal $\left(1 \mu \mathrm{g} \mathrm{L}{ }^{-1}\right)$ spiked in solutions containing different concentrations of $\mathrm{NaCl}(\%)$ in $\mathrm{He}(\mathrm{HMI})$ acquisition mode. HMI gas flow rate: (ロ) $0.30 \mathrm{~L} \mathrm{~min}^{-1} ;(\bigcirc) 0.40 \mathrm{~L} \mathrm{~min}^{-1} ;(\boldsymbol{\Delta}) 0.50 \mathrm{~L} \mathrm{~min}^{-1}$; $(\square) 0.60 \mathrm{~L} \mathrm{~min}^{-1} ;(\diamond) 0.70 \mathrm{~L} \mathrm{~min}^{-1} ;(\diamond) 0.80 \mathrm{~L} \mathrm{~min}^{-1}$.

In order to eliminate the effect of this polyatomic interference on As signal, CCT was combined with HMI mode. It was observed (Figure 1) that the increase in concentration of chloride ions did not cause positive 


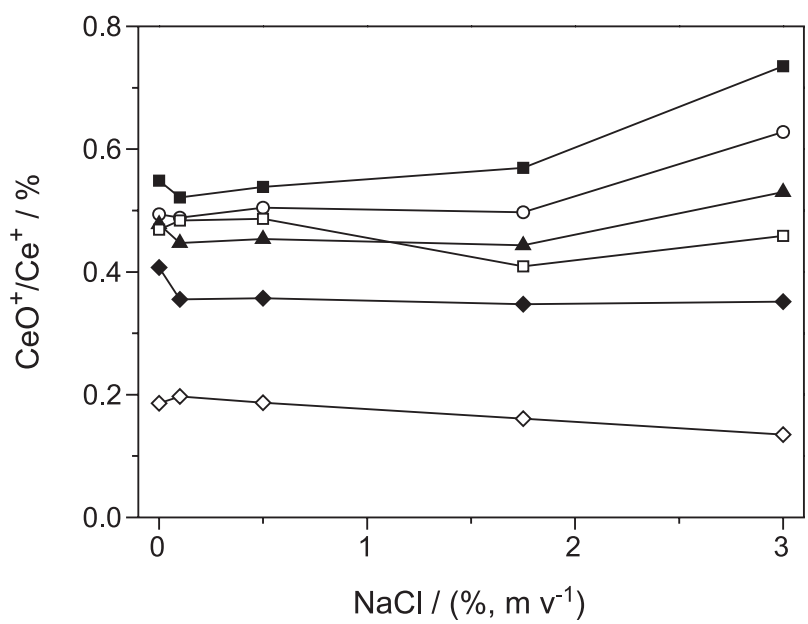

Figure 2. $\mathrm{CeO}^{+} / \mathrm{Ce}^{+}$ratio at different concentrations of $\mathrm{NaCl}(\%)$ and $\mathrm{HMI}$ (high matrix introduction) gas flow rate $\left(\mathrm{L} \mathrm{min}^{-1}\right)$ by ICP-MS (inductively coupled plasma mass spectrometry) in No gas (HMI) acquisition mode.

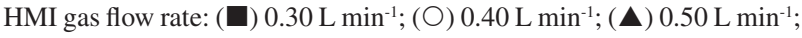
( $\square) 0.60 \mathrm{~L} \mathrm{~min}^{-1} ;(\diamond) 0.70 \mathrm{~L} \mathrm{~min}^{-1} ;(\diamond) 0.80 \mathrm{~L} \mathrm{~min}^{-1}$.

errors in ${ }^{75} \mathrm{As}^{+}$monitoring, however, for some flow rates it was noticed a mild suppression of the signal. In HMI gas flow rates higher than $0.60 \mathrm{~L} \mathrm{~min}^{-1}$, it was not observed significant signal difference when increasing $\mathrm{NaCl}$ concentration, which is a positive aspect of this procedure. The use of HMI system (in the same dilution gas flow rate of $0.60 \mathrm{~L} \mathrm{~min}^{-1}$ ) enabled the direct introduction of urine samples and dialysis solutions 2-fold diluted. ${ }^{18}$ Figure 2 shows an increase of oxide formation when increasing $\mathrm{NaCl}$ concentration, probably this is due to the decrease of plasma energy caused by plasma loading, in consequence of the presence of sample matrix. However, by increasing HMI gas flow rate $\left(>0.50 \mathrm{~L} \mathrm{~min}^{-1}\right)$ it was observed that $\mathrm{CeO}^{+} / \mathrm{Ce}^{+}$ ratio did not vary significantly in most $\mathrm{NaCl}$ concentrations. Previously, Hein et al. ${ }^{13}$ proposed an analytical procedure for analysis of highly saline samples by ICP-MS with an ultra-high matrix introduction system (UHMI). This procedure was suitable for determining metal ions, such as $\mathrm{Eu}$ and $\mathrm{U}$ in samples with salinities up to $5 \mathrm{~mol} \mathrm{~L}^{-1} \mathrm{NaCl}$. Accurate analysis of lanthanoids in environmental samples by ICP-MS equipped with HMI system was investigated by Celo et al. ${ }^{14}$ The amounts of oxide and hydroxide molecular species formed in the plasma were reduced by up to 5 times. In other studies, hydroxide formation was lower than $0.02 \%$ when HMI system was used. ${ }^{8,13,15}$

\section{Evaluation of accuracy and internal standardization}

The accuracy of the analytical procedure was evaluated by addition and recovery experiments and by analysis of the certified reference material of water (NIST SRM 1643e). Table 2 shows the recoveries and the relative standard deviations (RSDs) obtained for $\mathrm{Al}, \mathrm{Ag}, \mathrm{As}, \mathrm{B}, \mathrm{Ba}, \mathrm{Be}, \mathrm{Ca}$,

Table 2. Determination of $\mathrm{Al}, \mathrm{Ag}, \mathrm{As}, \mathrm{B}, \mathrm{Ba}, \mathrm{Be}, \mathrm{Ca}, \mathrm{Cd}, \mathrm{Co}, \mathrm{Cr}, \mathrm{Cu}, \mathrm{Fe}, \mathrm{Li}, \mathrm{Mg}, \mathrm{Mn}, \mathrm{Na}, \mathrm{Ni}, \mathrm{Pb}, \mathrm{Sb}, \mathrm{Se}, \mathrm{Tl}, \mathrm{V}$ and $\mathrm{Zn}$ (mean \pm standard deviation, $\mathrm{n}=3$ ) and recoveries in NIST SRM 1643e using ICP-MS

\begin{tabular}{lcccc}
\hline Isotope & Acquisition mode & Certified value $/(\mu \mathrm{g} \mathrm{L}-1)$ & Determined value / $\left(\mu \mathrm{g} \mathrm{L}^{-1}\right)$ & Recovery $(\mathrm{RSD}) / \%$ \\
\hline${ }^{7} \mathrm{Li}$ & No gas & $17.4 \pm 1.7$ & $18.8 \pm 0.4$ & $108(2.2)$ \\
${ }^{9} \mathrm{Be}$ & No gas & $14.0 \pm 0.2$ & $14.6 \pm 0.2$ & $104(1.1)$ \\
${ }^{11} \mathrm{~B}$ & No gas & $157.9 \pm 3.9$ & $170.4 \pm 4.7$ & $108(2.8)$ \\
${ }^{23} \mathrm{Na}$ & $\mathrm{He}(\mathrm{HMI})$ & $20740 \pm 260$ & $21350 \pm 260$ & $103(1.2)$ \\
${ }^{24} \mathrm{Mg}$ & $\mathrm{He}(\mathrm{HMI})$ & $8037 \pm 98$ & $7870 \pm 230$ & $98(2.9)$ \\
${ }^{27} \mathrm{Al}$ & $\mathrm{He}$ & $141.80 \pm 8.60$ & $139.2 \pm 1.2$ & $98(0.8)$ \\
${ }^{44} \mathrm{Ca}$ & $\mathrm{He}(\mathrm{HMI})$ & $32300 \pm 1100$ & $30400 \pm 1810$ & $94(6.0)$ \\
${ }^{51} \mathrm{~V}$ & $\mathrm{He}$ & $37.9 \pm 0.6$ & $38.2 \pm 0.4$ & $101(1.1)$ \\
${ }^{52} \mathrm{Cr}$ & $\mathrm{He}$ & $20.4 \pm 0.2$ & $20.5 \pm 0.1$ & $100(0.5)$ \\
${ }^{55} \mathrm{Mn}$ & $\mathrm{He}$ & $39.0 \pm 0.4$ & $41.2 \pm 0.3$ & $106(0.7)$ \\
${ }^{56} \mathrm{Fe}$ & $\mathrm{He}$ & $68.1 \pm 1.4$ & $103.4 \pm 0.4$ & $105(0.4)$ \\
${ }^{58} \mathrm{Ni}$ & $\mathrm{He}$ & $52.4 \pm 0.7$ & $93(0.6)$ \\
${ }^{59} \mathrm{Co}$ & $\mathrm{He}$ & $27.1 \pm 0.7$ & $25.59 \pm 0.03$ & $95(0.1)$ \\
${ }^{65} \mathrm{Cu}$ & $\mathrm{He}$ & $22.8 \pm 0.3$ & $22.77 \pm 0.06$ & $100(0.3)$ \\
${ }^{64} \mathrm{Zn}$ & $\mathrm{He}$ & $78.5 \pm 2.2$ & $90.1 \pm 0.8$ & $115(0.8)$ \\
${ }^{75} \mathrm{As}$ & $\mathrm{He}$ & $60.4 \pm 0.7$ & $64.5 \pm 0.7$ & $107(1.0)$ \\
${ }^{78} \mathrm{Se}$ & $\mathrm{He}$ & $11.97 \pm 0.1$ & $92(7.8)$ \\
${ }^{107} \mathrm{Ag}$ & $\mathrm{He}$ & $1.06 \pm 0.07$ & $11.0 \pm 0.9$ & $87(2.2)$ \\
${ }^{114} \mathrm{Cd}$ & $\mathrm{He}$ & $6.57 \pm 0.07$ & $0.93 \pm 0.02$ & $100(0.9)$ \\
${ }^{123} \mathrm{Sb}$ & $\mathrm{He}$ & $58.3 \pm 0.6$ & $6.57 \pm 0.06$ & $107(0.2)$ \\
${ }^{137} \mathrm{Ba}$ & $\mathrm{No} \mathrm{gas}$ & $544.2 \pm 5.8$ & $62.2 \pm 0.1$ & $103(0.6)$ \\
${ }^{205} \mathrm{Tl}$ & $\mathrm{He}$ & $7.45 \pm 0.09$ & $559.6 \pm 3.1$ & $97(0.8)$ \\
${ }^{208} \mathrm{~Pb}$ & $\mathrm{He}$ & $19.63 \pm 0.21$ & $7.24 \pm 0.06$ & $112(0.8)$ \\
& & & $22.02 \pm 0.18$ &
\end{tabular}

RSD: relative standard deviation; HMI: high matrix introduction. 
$\mathrm{Cd}, \mathrm{Co}, \mathrm{Cr}, \mathrm{Cu}, \mathrm{Fe}, \mathrm{Li}, \mathrm{Mg}, \mathrm{Mn}, \mathrm{Na}, \mathrm{Ni}, \mathrm{Pb}, \mathrm{Sb}, \mathrm{Se}, \mathrm{Tl}, \mathrm{V}$ and $\mathrm{Zn}$ in the SRM 1643e.

According to the recoveries obtained by NIST SRM $1643 \mathrm{e}$ analysis, it is possible to select three modes of acquisition for fresh water analysis: No gas, $\mathrm{He}$ and $\mathrm{He}$ (HMI). Recoveries for the CRM varied from $87\left({ }^{107} \mathrm{Ag}\right)$ to $115 \%\left({ }^{64} \mathrm{Zn}\right)$ and suitable recoveries, i.e., $87 \%$ for $\mathrm{Hg}$ and $107 \%$ for $\mathrm{U}$, were also obtained in addition and recovery experiments.

Calcium, $\mathrm{Na}$ and $\mathrm{Mg}$ were accurately determined in fresh water in He (HMI) mode, since this approach combines CCT, which controls spectral interferences, and HMI technology, which provides sample dilution by diluting the aerosol with argon gas at constant flow rate. This mode of operation improved matrix effects tolerance and provided the determination of elements at high concentrations simultaneously with elements at lower concentrations, thereby minimizing the need for recalibrations or even the use of other instrumental method with lower sensitivity.

Sea water was analyzed in HMI mode (Table 3), since when the instrument is operated in standard mode, analysis of samples with high contents of dissolved solids $\left(>0.2 \% \mathrm{~m} \mathrm{v}^{-1}\right)$ can cause salt deposition at the interfaces of the cones and ion lenses, and transport effects. The HMI system allows the introduction of samples with TDS around $3 \% \mathrm{~m} \mathrm{v}^{-1}$. For sample analysis without dilution, recoveries for ${ }^{27} \mathrm{Al},{ }^{64} \mathrm{Zn},{ }^{137} \mathrm{Ba},{ }^{202} \mathrm{Hg}$ and ${ }^{238} \mathrm{U}$ were not quantitative. Significant improvement of recoveries was observed when ${ }^{193} \mathrm{Ir}$ was used as IS for Ba, the recoveries were from 4782 and $5612 \%$ without IS to 96 and $117 \%$, respectively, when using IS. On the other hand, significant improvements were not observed for $\mathrm{Al}, \mathrm{Zn}, \mathrm{Hg}$ and $\mathrm{U}$ when using internal standardization. Good recoveries were obtained for all analytes in samples 2-fold diluted, using matrix matching without internal standardization. Recoveries ranged from $84\left({ }^{55} \mathrm{Mn}\right)$ to $115 \%\left({ }^{137} \mathrm{Ba}\right)$.

For sea water 5-fold diluted, even without matrix matching, appropriate recoveries were obtained in addition and recovery experiments, ranging from 80 to $118 \%$. IS was not required for accurate determination of ${ }^{9} \mathrm{Be},{ }^{52} \mathrm{Cr},{ }^{56} \mathrm{Fe}$, ${ }^{58} \mathrm{Ni},{ }^{65} \mathrm{Cu},{ }^{75} \mathrm{As},{ }^{78} \mathrm{Se},{ }^{202} \mathrm{Hg},{ }^{205} \mathrm{Tl},{ }^{208} \mathrm{~Pb}$ and ${ }^{238} \mathrm{U}$. However, significant improvement of recoveries was observed when ${ }^{72} \mathrm{Ge}$ was used as IS for ${ }^{27} \mathrm{Al}$ and ${ }^{55} \mathrm{Mn}$, ${ }^{195} \mathrm{Pt}$ was used as IS for ${ }^{107} \mathrm{Ag}$ and ${ }^{114} \mathrm{Cd}$ and when ${ }^{193} \mathrm{Ir}$ was used as IS for ${ }^{137} \mathrm{Ba},{ }^{205} \mathrm{Tl},{ }^{208} \mathrm{~Pb}$ and ${ }^{238} \mathrm{U}$. The improvement of recoveries with ${ }^{193} \mathrm{Ir}$ as IS for ${ }^{137} \mathrm{Ba},{ }^{205} \mathrm{Tl},{ }^{208} \mathrm{~Pb},{ }^{238} \mathrm{U}$; ${ }^{195} \mathrm{Pt}$ as IS for ${ }^{107} \mathrm{Ag},{ }^{114} \mathrm{Cd}$; and ${ }^{72} \mathrm{Ge}$ as IS for ${ }^{27} \mathrm{Al}$ and ${ }^{55} \mathrm{Mn}$ probably may be due to the similarity of the mass to charge ratios, $\mathrm{m} / \mathrm{z}$, of the IS evaluated with the analytes. ${ }^{19}$ However, as demonstrated by Barros et al..$^{18}$ and also obtained here, significant improvement of recoveries (110 and 118\%) were also reached with ${ }^{193} \mathrm{Ir}$ as IS for ${ }^{27} \mathrm{Al}$.

The isotopes ${ }^{7} \mathrm{Li},{ }^{9} \mathrm{Be},{ }^{11} \mathrm{~B}$ and ${ }^{137} \mathrm{Ba}$ were not affected by spectral or matrix interferences. Thus, no interference correction strategy was required and such elements were determined in No gas and No gas (HMI) modes in fresh water and sea water samples, respectively.

Best results were obtained for ${ }^{23} \mathrm{Na},{ }^{24} \mathrm{Mg},{ }^{27} \mathrm{Al},{ }^{44} \mathrm{Ca}$, ${ }^{51} \mathrm{~V},{ }^{52} \mathrm{Cr},{ }^{55} \mathrm{Mn},{ }^{56} \mathrm{Fe},{ }^{58} \mathrm{Ni},{ }^{59} \mathrm{Co},{ }^{65} \mathrm{Cu},{ }^{64} \mathrm{Zn},{ }^{75} \mathrm{As},{ }^{78} \mathrm{Se},{ }^{107} \mathrm{Ag}$, ${ }^{114} \mathrm{Cd},{ }^{123} \mathrm{Sb},{ }^{137} \mathrm{Ba},{ }^{202} \mathrm{Hg},{ }^{205} \mathrm{Tl},{ }^{208} \mathrm{~Pb},{ }^{238} \mathrm{U}$ using collision cell acquisition mode. Although He mode caused a significant reduction in net signals (from 2 to 3 times), the monitoring of some isotopes can be hampered by spectral interferences (polyatomic ions and double charge ions) formed by elements present in the sample or from species present in the plasma, such as argon, oxygen and nitrogen. ${ }^{6,7}$

It is possible to conclude that the developed procedure using specific operation mode for different analytes is accurate. For sea water, dilution gas flow rate of $0.60 \mathrm{~L} \mathrm{~min}^{-1}$ and 2-fold sample dilution were adopted. However, sea water 5-fold diluted, even without matrix matching, was also accurately analyzed for all analytes (IS required for $\mathrm{Al}, \mathrm{Ag}, \mathrm{Ba}, \mathrm{Cd}, \mathrm{Mn}, \mathrm{Pb}, \mathrm{Tl}$ and $\mathrm{U}$ ) except for $\mathrm{Zn}$, allowing 24 elements determination in a single ICP-MS run to satisfy four Brazilian regulations.

\section{Method detection limits}

The focus here was the simultaneous determination of 25 elements in a single ICP-MS run to satisfy four Brazilian regulations. ${ }^{2-5}$ Accuracy and sensitivity were evaluated for each element according to the respective mode of operation. Limits of detection (LOD) and quantification (LOQ) were calculated considering standard deviation (SD) for 10 measurements of a blank solution divided by slope of analytical curve multiplied by 3 (LOD) and 10 (LOQ), and then multiplied by the dilution factor. ${ }^{20}$ The isotopes and their best mode of acquisition, linear correlation coefficient, slope of analytical curves and LOD obtained for all analytes are shown for fresh and sea water samples in Table 4.

The developed procedure for water analysis by ICP-MS presented limits of detection and of quantification in compliance with Ordinance No. $2914^{2}$ and Resolutions Nos. 274, ${ }^{3} 357^{4}$ (including sea water, Tables IV and V) and $396,{ }^{5}$ allowing the determination of all elements simultaneously using each optimized acquisition mode.

\section{Sample analysis}

Table 5 shows the concentrations of Al, Ag, As, B, Ba, $\mathrm{Be}, \mathrm{Ca}, \mathrm{Cd}, \mathrm{Co}, \mathrm{Cr}, \mathrm{Cu}, \mathrm{Fe}, \mathrm{Li}, \mathrm{Mg}, \mathrm{Mn}, \mathrm{Na}, \mathrm{Ni}, \mathrm{Pb}, \mathrm{Sb}$, 
Table 3. Evaluation of combined use of HMI system, collision cell and IS for $\mathrm{Al}, \mathrm{Ag}, \mathrm{As}, \mathrm{Ba}, \mathrm{Be}, \mathrm{Cd}, \mathrm{Cr}, \mathrm{Cu}, \mathrm{Fe}, \mathrm{Hg}, \mathrm{Mn}, \mathrm{Ni}, \mathrm{Pb}, \mathrm{Se}, \mathrm{Tl}, \mathrm{U}$ and $\mathrm{Zn}$ determination in sea water by ICP-MS with and without matrix-matching. Mean (relative standard deviation, $\mathrm{n}=3$ )

\begin{tabular}{|c|c|c|c|c|c|c|c|c|c|}
\hline \multirow{3}{*}{ Isotope } & \multirow{3}{*}{$\begin{array}{l}\text { Acquisition } \\
\text { mode }\end{array}$} & \multirow{3}{*}{ IS } & \multirow{3}{*}{$\begin{array}{c}\text { Added } \\
\text { concentration / } \\
\left(\mu \mathrm{g} \mathrm{L}^{-1}\right)\end{array}$} & \multirow{2}{*}{\multicolumn{2}{|c|}{$\begin{array}{c}\begin{array}{c}\text { Matrix-matched } \\
\mathrm{NaCl} 3.5 \%{ }^{\mathrm{a}}\end{array} \\
\text { Recovery }(\mathrm{RSD}) / \%\end{array}$}} & \multirow{2}{*}{\multicolumn{2}{|c|}{$\begin{array}{c}\text { Matrix-matched } \\
\mathrm{NaCl} 1.75 \%^{\mathrm{b}}\end{array}$}} & \multirow{2}{*}{\multicolumn{2}{|c|}{$\begin{array}{c}\text { Without matrix-matched } \\
\text { Recovery (RSD) / \% }\end{array}$}} \\
\hline & & & & & & & & & \\
\hline & & & & Without IS & With IS & Without IS & With IS & Without IS & With IS \\
\hline \multirow[t]{2}{*}{${ }^{9} \mathrm{Be}$} & No gas (HMI) & NA & 10 & $96(7.9)$ & NA & $108(2.6)$ & NA & $98(11)$ & NA \\
\hline & & & 25 & $106(13)$ & & $114(0.7)$ & & $105(15)$ & \\
\hline \multirow[t]{2}{*}{${ }^{27} \mathrm{Al}$} & He (HMI) & $\mathrm{Ge}$ & 10 & $383(3.8)$ & NA & 109 (3.8) & NA & $78(1.3)$ & $115(6.0)$ \\
\hline & & & 25 & $183(5.0)$ & & $105(6.0)$ & & 79 (2.6) & $105(1.7)$ \\
\hline \multirow[t]{2}{*}{${ }^{52} \mathrm{Cr}$} & He (HMI) & NA & 10 & $106(2.1)$ & NA & $112(2.4)$ & NA & $105(5.5)$ & NA \\
\hline & & & 25 & $104(4.0)$ & & $111(3.4)$ & & $118(4.2)$ & \\
\hline \multirow[t]{2}{*}{${ }^{55} \mathrm{Mn}$} & $\mathrm{He}(\mathrm{HMI})$ & $\mathrm{Ge}$ & 10 & $92(5.1)$ & NA & $84(0.8)$ & NA & $86(1.4)$ & $101(3.1)$ \\
\hline & & & 25 & $105(11)$ & & $107(2.0)$ & & $86(3.7)$ & $107(1.8)$ \\
\hline \multirow[t]{2}{*}{${ }^{56} \mathrm{Fe}$} & He (HMI) & NA & 10 & $107(2.1)$ & NA & $100(1.7)$ & NA & $80(3.0)$ & NA \\
\hline & & & 25 & $103(0.2)$ & & $106(2.6)$ & & $82(4.5)$ & \\
\hline \multirow[t]{2}{*}{${ }^{58} \mathrm{Ni}$} & He (HMI) & NA & 10 & $93(3.7)$ & NA & $102(3.1)$ & NA & $88(7.5)$ & NA \\
\hline & & & 25 & $103(0.2)$ & & $103(1.7)$ & & $108(4.5)$ & \\
\hline \multirow[t]{2}{*}{${ }^{65} \mathrm{Cu}$} & He (HMI) & NA & 10 & $106(0.8)$ & NA & $110(2.6)$ & NA & $88(3.3)$ & NA \\
\hline & & & 25 & $100(1.6)$ & & $108(3.1)$ & & $103(3.7)$ & \\
\hline \multirow[t]{2}{*}{${ }^{64} \mathrm{Zn}$} & $\mathrm{He}(\mathrm{HMI})$ & NA & 10 & $19(5.0)$ & NA & $105(6.8)$ & NA & $59(24)$ & NA \\
\hline & & & 25 & $53(5.4)$ & & $110(6.9)$ & & $164(7.9)$ & \\
\hline \multirow[t]{2}{*}{${ }^{75} \mathrm{As}$} & He (HMI) & NA & 10 & $107(2.7)$ & NA & $111(1.9)$ & NA & $99(0.2)$ & NA \\
\hline & & & 25 & $101(2.0)$ & & $111(4.7)$ & & $116(4.7)$ & \\
\hline \multirow[t]{2}{*}{${ }^{78} \mathrm{Se}$} & He (HMI) & NA & 10 & $123(5.0)$ & NA & $112(7.8)$ & NA & $89(8.1)$ & NA \\
\hline & & & 25 & $102(2.7)$ & & $112(3.3)$ & & $109(8.4)$ & \\
\hline \multirow[t]{2}{*}{${ }^{107} \mathrm{Ag}$} & No gas (HMI) & $\mathrm{Pt}$ & 10 & $73(4.0)$ & NA & $99(1.7)$ & NA & $67(9.4)$ & $88(6.9)$ \\
\hline & & & 25 & $95(0.6)$ & & $110(1.0)$ & & $70(15)$ & $93(5.5)$ \\
\hline \multirow[t]{2}{*}{${ }^{114} \mathrm{Cd}$} & $\mathrm{He}(\mathrm{HMI})$ & $\mathrm{Pt}$ & 10 & $96(11)$ & NA & $99(10)$ & NA & $73(7.3)$ & $95(6.1)$ \\
\hline & & & 25 & $107(1.4)$ & & 109 (1.3) & & $76(13)$ & $99(6.7)$ \\
\hline \multirow[t]{2}{*}{${ }^{137} \mathrm{Ba}$} & No gas (HMI) & $\mathrm{Ir}$ & 10 & $4782(3.2)$ & $96(3.0)$ & $105(0.8)$ & NA & $82(2.5)$ & $104(2.4)$ \\
\hline & & & 25 & $5612(3.0)$ & $117(1.1)$ & $115(3.3)$ & & $83(4.8)$ & $106(2.7)$ \\
\hline \multirow[t]{2}{*}{${ }^{202} \mathrm{Hg}$} & $\mathrm{He}(\mathrm{HMI})$ & NA & 0.2 & 37 (18) & NA & $85(4.1)$ & NA & $84(3.8)$ & NA \\
\hline & & & 0.5 & $59(21)$ & & $107(2.8)$ & & $118(21)$ & \\
\hline \multirow[t]{2}{*}{${ }^{205} \mathrm{Tl}$} & $\mathrm{He}(\mathrm{HMI})$ & $\mathrm{Ir}$ & 10 & $97(9.3)$ & NA & $101(10)$ & NA & $80(6.3)$ & $100(1.6)$ \\
\hline & & & 25 & $108(0.2)$ & & $112(0.3)$ & & $79(13)$ & $101(0.6)$ \\
\hline \multirow[t]{2}{*}{${ }^{208} \mathrm{~Pb}$} & He (HMI) & $\mathrm{Ir}$ & 10 & $101(1.0)$ & NA & $107(1.5)$ & NA & $85(4.5)$ & $98(3.4)$ \\
\hline & & & 25 & $101(0.4)$ & & $106(2.1)$ & & $87(2.3)$ & $98(2.8)$ \\
\hline \multirow[t]{2}{*}{${ }^{238} \mathrm{U}$} & No gas (HMI) & $\mathrm{Ir}$ & 10 & $2(2.2)$ & NA & $104(1.1)$ & NA & $85(7.1)$ & $107(3.4)$ \\
\hline & & & 25 & $56(0.4)$ & & $113(0.5)$ & & 81 (13) & $102(4.6)$ \\
\hline
\end{tabular}

IS: internal standard; RSD: relative standard deviation; HMI: high matrix introduction; NA: not applicable. ${ }^{2}$ Analytical solutions prepared by matrix-matching

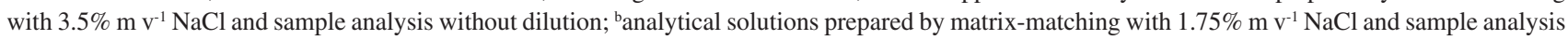
after 2-fold dilution; canalytical solutions prepared with $1 \% \mathrm{v} \mathrm{v}^{-1} \mathrm{HNO}_{3}$ and samples analysis after 5 -fold dilution.

Se, Tl, Hg, V, U and Zn found in six bottled mineral water, one drinking water, one artesian well water and one sea water samples. All fresh and sea water samples analyzed presented concentrations below the maximum allowed limits imposed by Ordinance No. $2914^{2}$ and Resolutions Nos. $274,{ }^{3} 357^{4}$ and 396.5

\section{Conclusions}

A procedure for analysis of elemental composition of water samples by ICP-MS was developed, in order to answer the Ordinance No. 2914 of the Ministry of Health, the Resolutions Nos. 357 and 396 of CONAMA and the Resolution RDC No. 274 of ANVISA. The use of ICP-MS operated in different acquisition modes allowed precise, accurate and simultaneous determinations of elements at large concentration ranges and samples with high salts concentration in a single run. The measurements performed in He mode allowed accurate determinations of elements whose isotopes were affected by spectral interferences. 
Table 4. Permissible maximum limits (PML), linear correlation coefficients and limits of quantification obtained for Al, Ag, As, B, Ba, Be, Ca, Cd, Co, $\mathrm{Cr}, \mathrm{Cu}, \mathrm{Fe}, \mathrm{Li}, \mathrm{Mg}, \mathrm{Mn}, \mathrm{Na}, \mathrm{Ni}, \mathrm{Pb}, \mathrm{Sb}, \mathrm{Se}, \mathrm{Tl}, \mathrm{Hg}, \mathrm{V}, \mathrm{U}$ and $\mathrm{Zn}$ in fresh and sea water samples

\begin{tabular}{|c|c|c|c|c|c|c|c|c|}
\hline \multirow[b]{2}{*}{ Sample } & \multirow[b]{2}{*}{ Isotope } & \multirow{2}{*}{$\begin{array}{l}\text { Acquisition } \\
\text { mode }\end{array}$} & \multirow[b]{2}{*}{$\mathrm{r}$} & \multirow[b]{2}{*}{$\mathrm{LOQ} /\left(\mu \mathrm{g} \mathrm{L} \mathrm{L}^{-1}\right)$} & \multicolumn{4}{|c|}{$\mathrm{PML} /\left(\mu \mathrm{g} \mathrm{L}^{-1}\right)$} \\
\hline & & & & & Ordinance $2914^{2}$ & RDC $274^{3}$ & $\begin{array}{c}\text { CONAMA } \\
357^{4} \text { a }\end{array}$ & $\begin{array}{c}\text { CONAMA } \\
396^{5} \mathrm{~b}\end{array}$ \\
\hline Fresh water & ${ }^{7} \mathrm{Li}$ & No gas & 0.9996 & 0.0024 & NA & NA & 2500 & NA \\
\hline Sea water & & NA & NA & NA & & & NA & \\
\hline Fresh water & ${ }^{9} \mathrm{Be}$ & No gas & 0.9995 & 0.0018 & NA & NA & 40 & 4.0 \\
\hline Sea water & & No gas (HMI) & 0.9999 & 9.7 & & & 5.3 & NA \\
\hline Fresh water & ${ }^{11} \mathrm{~B}$ & No gas & 0.9998 & 5.0 & NA & 5000 & 500 & 500 \\
\hline Sea water & & NA & NA & NA & & NA & NA & NA \\
\hline Fresh water & ${ }^{23} \mathrm{Na}$ & $\mathrm{He}(\mathrm{HMI})$ & 0.9995 & 0.060 & NA & $60 \times 10^{4}$ & NA & $20 \times 10^{4}$ \\
\hline Sea water & & NA & NA & NA & & NA & & NA \\
\hline Fresh water & ${ }^{24} \mathrm{Mg}$ & $\mathrm{He}(\mathrm{HMI})$ & 1 & 0.0027 & NA & $65 \times 10^{3}$ & NA & NA \\
\hline Sea water & & NA & NA & NA & & NA & & \\
\hline Fresh water & ${ }^{27} \mathrm{Al}$ & $\mathrm{He}$ & 0.9995 & 2.8 & $\mathrm{NA}$ & NA & 100 & 200 \\
\hline Sea water & & $\mathrm{He}(\mathrm{HMI})$ & 0.9999 & 22 & & & 1500 & NA \\
\hline Fresh water & ${ }^{44} \mathrm{Ca}$ & $\mathrm{He}(\mathrm{HMI})$ & 1 & 0.18 & NA & $25 \times 10^{4}$ & NA & NA \\
\hline Sea water & & NA & NA & NA & & NA & & \\
\hline Fresh water & ${ }^{51} \mathrm{~V}$ & $\mathrm{He}$ & 0.9999 & 0.0030 & NA & NA & 100 & 50 \\
\hline Sea water & & NA & NA & NA & & & NA & NA \\
\hline Fresh water & ${ }^{52} \mathrm{Cr}$ & $\mathrm{He}$ & 0.9998 & 0.030 & 50 & 50 & 50 & 50 \\
\hline Sea water & & $\mathrm{He}(\mathrm{HMI})$ & 0.9998 & 2.6 & NA & NA & 50 & NA \\
\hline Fresh water & ${ }^{55} \mathrm{Mn}$ & $\mathrm{He}$ & 0.9997 & 0.27 & NA & 500 & 100 & 100 \\
\hline Sea water & & $\mathrm{He}(\mathrm{HMI})$ & 0.9999 & 0.93 & & NA & 100 & NA \\
\hline Fresh water & ${ }^{56} \mathrm{Fe}$ & $\mathrm{He}$ & 0.9999 & 0.24 & $\mathrm{NA}$ & NA & 300 & 300 \\
\hline Sea water & & $\mathrm{He}(\mathrm{HMI})$ & 0.9999 & 8.4 & & & 300 & NA \\
\hline Fresh water & ${ }^{58} \mathrm{Ni}$ & $\mathrm{He}$ & 0.9999 & 0.00060 & 70 & 20 & 25 & 20 \\
\hline Sea water & & $\mathrm{He}(\mathrm{HMI})$ & 0.9999 & 3.4 & NA & NA & 25 & NA \\
\hline Fresh water & ${ }^{59} \mathrm{Co}$ & $\mathrm{He}$ & 0.9998 & 0.0060 & $\mathrm{NA}$ & NA & 50 & NA \\
\hline Sea water & & NA & NA & NA & & & NA & \\
\hline Fresh water & ${ }^{65} \mathrm{Cu}$ & $\mathrm{He}$ & 0.9998 & 0.030 & 2000 & 1000 & 9.0 & 10 \\
\hline Sea water & & $\mathrm{He}(\mathrm{HMI})$ & 1 & 1.2 & NA & NA & 5.0 & NA \\
\hline Fresh water & ${ }^{64} \mathrm{Zn}$ & $\mathrm{He}$ & 0.998 & 0.93 & 5000 & NA & 180 & 5000 \\
\hline Sea water & & $\mathrm{He}(\mathrm{HMI})$ & 0.9997 & 2.0 & NA & & 90 & NA \\
\hline Fresh water & ${ }^{75} \mathrm{As}$ & $\mathrm{He}$ & 0.9995 & 0.030 & 10 & 10 & 1.0 & 1.0 \\
\hline Sea water & & $\mathrm{He}(\mathrm{HMI})$ & 0.9999 & 0.12 & NA & NA & 1.0 & NA \\
\hline Fresh water & ${ }^{78} \mathrm{Se}$ & $\mathrm{He}$ & 0.9996 & 0.51 & 10 & 10 & 10 & 10 \\
\hline Sea water & & $\mathrm{He}(\mathrm{HMI})$ & 0.9998 & 2.6 & NA & NA & 10 & NA \\
\hline Fresh water & ${ }^{107} \mathrm{Ag}$ & $\mathrm{He}$ & 0.9999 & 0.0030 & NA & NA & 10 & 100 \\
\hline Sea water & & No gas (HMI) & 0.9989 & 2.9 & & & 5.0 & NA \\
\hline Fresh water & ${ }^{123} \mathrm{Sb}$ & $\mathrm{He}$ & 0.9999 & 0.09 & 5.0 & 5.0 & 5.0 & 5.0 \\
\hline Sea water & & NA & NA & NA & NA & NA & NA & NA \\
\hline Fresh water & ${ }^{114} \mathrm{Cd}$ & $\mathrm{He}$ & 0.9997 & 0.0090 & 5.0 & 3.0 & 1.0 & 5.0 \\
\hline Sea water & & $\mathrm{He}(\mathrm{HMI})$ & 0.9999 & 0.24 & NA & NA & 5.0 & NA \\
\hline Fresh water & ${ }^{137} \mathrm{Ba}$ & No gas & 0.9994 & 0.021 & 700 & 700 & 700 & 700 \\
\hline Sea water & & No gas (HMI) & 1 & 32 & NA & NA & 1000 & NA \\
\hline Fresh water & ${ }^{202} \mathrm{Hg}$ & $\mathrm{He}$ & 0.9989 & 0.060 & 1.0 & 1.0 & 0.2 & 1.0 \\
\hline Sea water & & $\mathrm{He}(\mathrm{HMI})$ & 0.9990 & 0.24 & NA & NA & 0.2 & NA \\
\hline Fresh water & ${ }^{205} \mathrm{Tl}$ & $\mathrm{He}$ & 0.9998 & 0.00060 & NA & NA & 100 & NA \\
\hline Sea water & & $\mathrm{He}(\mathrm{HMI})$ & 1 & 0.15 & & & 100 & \\
\hline Fresh water & ${ }^{208} \mathrm{~Pb}$ & $\mathrm{He}$ & 0.9998 & 0.0060 & 10 & 10 & 10 & 10 \\
\hline Sea water & & $\mathrm{He}(\mathrm{HMI})$ & 0.9999 & 0.21 & NA & NA & 10 & NA \\
\hline Fresh water & ${ }^{238} \mathrm{U}$ & No gas & 0.9993 & 0.00030 & 30 & NA & 20 & 15 \\
\hline Sea water & & No gas (HMI) & 0.9999 & 14 & $\mathrm{NA}$ & & 500 & NA \\
\hline
\end{tabular}

a Table I, class I; 'bround water for human consumption. PML: permissible maximum limits; LOQ: limit of quantification; NA: not applicable. 
Table 5. Determination of $\mathrm{Al}, \mathrm{Ag}, \mathrm{As}, \mathrm{B}, \mathrm{Ba}, \mathrm{Be}, \mathrm{Ca}, \mathrm{Cd}, \mathrm{Co}, \mathrm{Cr}, \mathrm{Cu}, \mathrm{Fe}, \mathrm{Li}, \mathrm{Mg}, \mathrm{Mn}, \mathrm{Na}, \mathrm{Ni}, \mathrm{Pb}, \mathrm{Sb}, \mathrm{Se}, \mathrm{Tl}, \mathrm{Hg}, \mathrm{V}, \mathrm{U}$ and $\mathrm{Zn}$ (mean \pm standard deviation, $\mathrm{n}=3$ ) in samples of mineral water (A-F), groundwater, drinking water and sea water by ICP-MS

\begin{tabular}{|c|c|c|c|c|c|c|c|c|c|}
\hline \multirow{2}{*}{ Isotope } & \multicolumn{9}{|c|}{ Sample / $\left(\mu \mathrm{g} \mathrm{L} \mathrm{L}^{-1}\right)$} \\
\hline & A & $\mathrm{B}$ & $\mathrm{C}$ & $\mathrm{D}$ & $\mathrm{E}$ & $\mathrm{F}$ & Ground water & Drinking water & Sea water \\
\hline${ }^{7} \mathrm{Li}$ & $6.2 \pm 0.5$ & $2.0 \pm 0.2$ & $1.8 \pm 0.2$ & $7.2 \pm 0.5$ & $0.52 \pm 0.08$ & $7.27 \pm 0.31$ & $1.3 \pm 0.2$ & $1.4 \pm 0.2$ & NA \\
\hline${ }^{9} \mathrm{Be}$ & $0.003 \pm 0.001$ & $0.007 \pm 0.002$ & $0.039 \pm 0.004$ & $0.004 \pm 0.001$ & $0.002 \pm 0.001$ & $<0.0006$ & $0.016 \pm 0.001$ & $0.012 \pm 0.001$ & $<3.23$ \\
\hline${ }^{11} \mathrm{~B}$ & $3.1 \pm 0.3$ & $<1.68$ & $<1.68$ & $<1.68$ & $<1.68$ & $10.4 \pm 0.3$ & $<1.68$ & $<1.68$ & NA \\
\hline${ }^{23} \mathrm{Na}^{\mathrm{a}}$ & $22.5 \pm 1.0$ & $7.50 \pm 0.04$ & $1.62 \pm 0.04$ & $3.21 \pm 0.06$ & $3.41 \pm 0.08$ & $10.9 \pm 0.3$ & $3.87 \pm 0.06$ & $3.14 \pm 0.04$ & NA \\
\hline${ }^{24} \mathrm{Mg}^{\mathrm{a}}$ & $0.43 \pm 0.02$ & $4.32 \pm 0.01$ & $13.4 \pm 0.4$ & $19.3 \pm 0.4$ & $5.64 \pm 0.02$ & $39.2 \pm 1.0$ & $6.33 \pm 0.06$ & $5.09 \pm 0.08$ & NA \\
\hline${ }^{27} \mathrm{Al}$ & $<0.943$ & $<0.943$ & $<0.943$ & $<0.943$ & $<0.943$ & $<0.943$ & $<0.943$ & $<0.943$ & $<7.35$ \\
\hline${ }^{44} \mathrm{Ca}^{\mathrm{a}}$ & $11.4 \pm 0.4$ & $9.4 \pm 0.3$ & $22.2 \pm 0.5$ & $36.1 \pm 1.4$ & $12.1 \pm 0.2$ & $57.9 \pm 1.3$ & $14.0 \pm 0.4$ & $10.9 \pm 0.2$ & NA \\
\hline${ }^{51} \mathrm{~V}$ & $0.93 \pm 0.01$ & $1.00 \pm 0.02$ & $0.23 \pm 0.01$ & $4.16 \pm 0.01$ & $1.57 \pm 0.02$ & $0.16 \pm 0.01$ & $7.33 \pm 0.06$ & $3.65 \pm 0.06$ & NA \\
\hline${ }^{52} \mathrm{Cr}$ & $5.28 \pm 0.05$ & $0.99 \pm 0.01$ & $0.32 \pm 0.01$ & $1.09 \pm 0.01$ & $0.864 \pm 0.004$ & $0.19 \pm 0.01$ & $0.58 \pm 0.01$ & $0.18 \pm 0.01$ & $<0.87$ \\
\hline${ }^{55} \mathrm{Mn}$ & $<0.092$ & $0.29 \pm 0.01$ & $<0.092$ & $<0.092$ & $<0.092$ & $<0.092$ & $<0.092$ & $0.188 \pm 0.003$ & $<0.31$ \\
\hline${ }^{56} \mathrm{Fe}$ & $<0.083$ & $<0.083$ & $<0.083$ & $<0.083$ & $<0.083$ & $<0.083$ & $0.12 \pm 0.02$ & $<0.083$ & $<2.79$ \\
\hline${ }^{58} \mathrm{Ni}$ & $0.018 \pm 0.003$ & $0.06 \pm 0.01$ & $<0.0002$ & $0.011 \pm 0.001$ & $0.24 \pm 0.01$ & $0.050 \pm 0.004$ & $2.69 \pm 0.02$ & $0.14 \pm 0.01$ & $<1.13$ \\
\hline${ }^{59} \mathrm{Co}$ & $<0.002$ & $<0.002$ & $<0.002$ & $<0.002$ & $<0.002$ & $0.003 \pm 0.001$ & $<0.002$ & $<0.002$ & NA \\
\hline${ }^{65} \mathrm{Cu}$ & $<0.014$ & $<0.014$ & $<0.014$ & $<0.014$ & $0.110 \pm 0.006$ & $0.03 \pm 0.01$ & $1.8 \pm 0.1$ & $0.97 \pm 0.01$ & $1.55 \pm 0.05$ \\
\hline${ }^{64} \mathrm{Zn}$ & $<0.308$ & $<0.308$ & $<0.308$ & $<0.308$ & $<0.308$ & $<0.308$ & $62.6 \pm 1.78$ & $8.50 \pm 0.49$ & $11.9 \pm 1.1$ \\
\hline${ }^{75} \mathrm{As}$ & $<0.01$ & $<0.01$ & $<0.01$ & $2.59 \pm 0.07$ & $0.75 \pm 0.06$ & $0.48 \pm 0.04$ & $0.08 \pm 0.01$ & $0.06 \pm 0.02$ & $1.1 \pm 0.2$ \\
\hline${ }^{78} \mathrm{Se}$ & $0.46 \pm 0.06$ & $<0.172$ & $<0.172$ & $<0.172$ & $<0.172$ & $0.29 \pm 0.08$ & $<0.172$ & $<0.172$ & $0.9 \pm 0.4$ \\
\hline${ }^{107} \mathrm{Ag}$ & $0.012 \pm 0.003$ & $<0.0008$ & $0.035 \pm 0.004$ & $0.002 \pm 0.001$ & $<0.0008$ & $0.04 \pm 0.07$ & $0.02 \pm 0.01$ & $0.499 \pm 0.004$ & $<0.96$ \\
\hline${ }^{114} \mathrm{Cd}$ & $<0.003$ & $<0.003$ & $<0.003$ & $<0.003$ & $<0.003$ & $0.01 \pm 0.02$ & $0.008 \pm 0.003$ & $<0.003$ & $0.50 \pm 0.02$ \\
\hline${ }^{123} \mathrm{Sb}$ & $0.51 \pm 0.01$ & $0.21 \pm 0.01$ & $0.44 \pm 0.02$ & $0.92 \pm 0.01$ & $0.007 \pm 0.002$ & $2.76 \pm 0.01$ & $0.001 \pm 0.004$ & $0.007 \pm 0.002$ & NA \\
\hline${ }^{137} \mathrm{Ba}$ & $1.0 \pm 0.1$ & $51.5 \pm 5.9$ & $24.9 \pm 1.9$ & $53.4 \pm 8.1$ & $52.97 \pm 2.7$ & $121 \pm 18$ & $3.7 \pm 0.9$ & $60.5 \pm 1.4$ & $<10.68$ \\
\hline${ }^{202} \mathrm{Hg}$ & $0.22 \pm 0.01$ & $0.21 \pm 0.01$ & $0.179 \pm 0.003$ & $0.160 \pm 0.002$ & $0.160 \pm 0.005$ & $0.19 \pm 0.01$ & $0.64 \pm 0.01$ & $0.54 \pm 0.01$ & $<0.08$ \\
\hline${ }^{205} \mathrm{Tl}$ & $<0.0002$ & $<0.0002$ & $0.018 \pm 0.001$ & $0.046 \pm 0.002$ & $<0.0002$ & $<0.0002$ & $0.0030 \pm 0.0001$ & $0.0040 \pm 0.0001$ & $0.8 \pm 0.2$ \\
\hline${ }^{208} \mathrm{~Pb}$ & $<0.0018$ & $<0.0018$ & $<0.0018$ & $<0.0018$ & $<0.0018$ & $<0.0018$ & $<0.0018$ & $<0.0018$ & $0.13 \pm 0.02$ \\
\hline${ }^{238} \mathrm{U}$ & $0.31 \pm 0.05$ & $0.03 \pm 0.01$ & $0.21 \pm 0.01$ & $0.22 \pm 0.07$ & $0.008 \pm 0.004$ & $2.0 \pm 0.6$ & $0.004 \pm 0.003$ & $0.012 \pm 0.01$ & $<4.58$ \\
\hline
\end{tabular}

${ }^{a}$ Concentration in $\mathrm{mg} \mathrm{L}^{-1}$, mean \pm standard deviation, $\mathrm{n}=3$. NA: not applicable.

Additionally, HMI system allowed the determination of $\mathrm{Na}, \mathrm{Ca}$ and $\mathrm{Mg}$ in fresh water samples without requiring any further dilution and sea water analysis with only 2-fold dilution, demonstrating the improvement in plasma robustness when operating ICP-MS in HMI mode. Thus, the determination of trace elements can be made simultaneously to elements in higher concentrations. These benefits translate into simplicity, high sample throughput, time saving and reliable analysis.

\section{Acknowledgments}

The authors are grateful to the Coordenação de Aperfeiçoamento de Pessoal de Nível Superior (CAPES/PNPD, Department of Chemistry, Graduate Program in Chemistry) and to the Conselho Nacional de Desenvolvimento Científico e Tecnológico (CNPq, 141634/2017-0 and 303107/2013-8) for fellowships and financial support. The authors also would like to thank Agilent Technologies for technical support and by providing the ICP-MS instrument.

\section{References}

1. Sela, H.; Karpas, Z.; Cohen, H.; Tal, A.; Zeiri, Y.; Biol. Trace Elem. Res. 2013, 155, 209.

2. Ministério da Saúde, Portaria No. 2914, de 12 de dezembro de 2011, Dispõe sobre os Procedimentos de Controle e de Vigilância da Qualidade da Água para Consumo Humano e seu Padrão de Potabilidade; DOU, Brasília, Brasil, 2011. Available at http://site.sabesp.com.br/site/uploads/file/asabesp_doctos/ PortariaMS291412122011.pdf, accessed in March 2018.

3. Agência Nacional de Vigilância Sanitária (ANVISA); Resolução RDC No. 274 de 22 de setembro de 2005; Regulamento Técnico para Águas Envasadas e Gelo; DOU, Brasil, 2005. Available at http://portal.anvisa.gov.br/documents/33916/394219/ RDC_274_2005.pdf/19d98e61-fa3b-41df-9342-67e0167bf550, accessed in March 2018.

4. Conselho Nacional do Meio Ambiente (CONAMA); Resolução No. 357, de 17 de março de 2005, Dispõe sobre a Classificação dos Corpos de Água e Diretrizes Ambientais para o seu Enquadramento, bem como Estabelece as Condições e Padrões de Lançamento de Efluentes, e Dá Outras Providências; DOU, 
Brasília, Brasil, 2005, No. 053, p. 58-63. Available at http:// www.mma.gov.br/port/conama/legiabre.cfm?codlegi $=459$, accessed in March 2018.

5. Conselho Nacional do Meio Ambiente (CONAMA); Resolução No. 396, de 3 de abril de 2008, Dispõe sobre a Classificação e Diretrizes Ambientais para o Enquadramento das Águas Subterrâneas e Dá Outras Providências; DOU, Brasília, Brasil, 2008, No. 066, seção 1, p. 64-68. Available at http://www.mma. gov.br/port/conama/legiabre.cfm?codlegi=562, accessed in March 2018.

6. Thomas, R.; Practical Guide to ICP-MS, $3^{\text {rd }}$ ed.; CRC Press: Boca Raton, New York, 2013, p. 73-90.

7. D'ilio, S.; Violante, N.; Majorani, C.; Petrucci, F.; Anal. Chim. Acta 2011, 698, 6.

8. Wilbur, S. M.; Jones, L. C.; Open Chem. Biomed. Methods J. 2010, 3, 135.

9. McCurdy, E.; Woods, G.; J. Anal. At. Spectrom. 2004, 5, 607.

10. Agilent Technologies; Agilent 7800 ICP-MS: Plasma Robustness in ICP-MS Benefits of a Low CeO/Ce Ratio, 59908060EN; Agilent Technologies: Santa Clara, USA, 2015. Available at https://www.agilent.com/cs/library/articlereprints/ public/5990_8060EN.pdf, accessed in March 2018.

11. Larivière, D.; Tremblay, M.; Durand-Jézéquel, M.; Tolmachev, S.; Anal Bioanal. Chem. 2012, 403, 409.
12. Novotnik, B.; Zuliani, T.; Martincic, A.; Scancar, J.; Milacic, R.; J. Anal. At. Spectrom. 2012, 27, 488.

13. Hein, C.; Sander, J. M.; Kautenburger, R.; Talanta 2017, 164, 477.

14. Celo, V.; Dabek-Zlotorzynska, E.; Zhao, J.; Okonskaia, I.; Bowman, D.; Anal. Chim. Acta 2011, 706, 89.

15. Döker, S.; Anal. Methods 2017, 9, 1710.

16. Döker, S.; Uslu, M.; Food Anal. Methods 2013, 7, 683.

17. Amaral, C. D. B.; Amais, R. S.; Fialho, L. L.; Schiavo, D.; Morim, T. A.; Nogueira, A. R. A.; Rocha, F. R. P.; Nóbrega, J. A.; Anal. Methods 2015, 7, 1215.

18. Barros, A. I.; Pinheiro, F. C.; Lorençatto, R.; Amaral, C. D. B.; Nóbrega, J. A.; Talanta 2018, 178, 805.

19. Amaral, C. D. B.; Machado, R. C.; Virgilio, A.; Schiavo, D.; Nogueira, A. R. A.; Nóbrega, J. A.; J. Anal. At. Spectrom. 2016, $31,1179$.

20. Thomsen, V.; Schatzlein, D.; Mercuro, D.; Spectroscopy 2003, $18,112$.

Submitted: January 29, 2018

Published online: April 2, 2018 